\title{
Investigación \\ Restauración cinematográfica. Tierra de nadie
}

Gian Luca Farinelli > Davide Pozzi

Cineteca di Bologna (Italia)

\section{Resumen}

La restauración cinematográfica es un campo de investigación y especialización profesional con una corta trayectoria. El predominio del valor comercial otorgado a las películas ha sido un factor clave para que el cine no se tomara en consideración como forma de expresión cultural que fuese necesario conservar y restaurar. Se han necesitado muchos años para que el cine sea reconocido como bien cultural. Los autores de este articulo realizan un repaso por la historia de esta transformación ideológica que afecta a la vida de las películas, analizando la naturaleza del cine, las instancias encargadas de su protección, los factores de degradación de las películas y la evolución de las técnicas de restauración, ofreciendo un panorama amplio y detallado de los principales aspectos que giran en torno a la restauración cinematográfica.

\section{Palabras clave}

Cinematografia

Filmotecas

Historia

Intervención

Restauración

Soporte filmico
Actualmente, la disciplina de la restauración cinematográfica es un territorio de límites inciertos, frecuentado por todos y por ninguno, aún sin reglas codificadas, sin metodologías consensuadas, sin espacios de formación que preparen nuevas figuras profesionales capacitadas para trabajar en una disciplina que experimenta una época de profundas transformaciones.

Tampoco hay que olvidar que la restauración de las obras figurativas no comienza a plantearse como una exigencia hasta la época moderna, en la segunda mitad del siglo XVIII. Desde hace sólo poco tiempo la tradición de restauración de las artes mayores reconoce el significado que tiene el estudio, la investigación y el conocimiento profundo de la obra que cada intervención requiere. En este sentido, son fundamentales las reflexiones de Cesare Brandi, que expresó a lo largo de los sesenta años que duró su trabajo vinculado al Istituto Centrale di Restauro (junto con C.G. Argan en 1938) y a través de una serie de publicaciones que constituyen hoy un punto de referencia para todos los que trabajan en este sector.

El cine tiene características propias, pero no es el primer arte serial que requiere intervenciones de restauración. Muchas son las obras de arte seriales: los libros, grabados, y también las estatuas de bronce de las que, a partir de un modelo único, se sacan varios cat cos. Por tanto, podemos esperar que en los próximos decenios se abra camino una actitud científica rigurosa y consensuada también en el campo de la restauración cinematográfica.

\section{¿Por qué se restaura?}

Dominados como estamos por la "propaganda de las ventas", por la idea de que el futuro será mejor que el pasado, sólo desde hace poquísimo tiempo ha comenzado a extenderse, entre un público cada vez más amplio, un nuevo interés hacia la historia del cine descubriendo la extraordinaria vitalidad, valor artístico y comercial del patrimonio cinematográfico del pasado.

Pero ¿cómo surge este sentimiento, hoy bastante difundido (incluso entre los que no se encargan de este trabajo), sobre la necesi dad de conservar y restaurar un film? De hecho, bien mirado, la idea de restauración cinematográfica se contradice con la idea que el sentido común ha mantenido durante mucho tiempo sobre la naturaleza del cine.

Basta con releer las páginas que el padre de la crítica francesa, André Bazin, fundador de Cahiers y promotor de la Nouvelle Vague, dedicó a la ontología cinematográfica, páginas en las que señala al cine como punto de llegada del arte que, desde los primeros esgrafiados, pasando por los sarcófagos egipcios, quiere ser el remedio a la muerte, a la finitud humana. El cine, según Bazin, resuelve el deseo de eternidad congelando, para siempre, rostros, momentos de vida, pensamientos. 
"Un psicoanálisis de las artes plásticas podría considerar la práctica del embalsamado como un hecho fundamental en su génesis En los origenes de la pintura y de la escultura se encontraría el complejo de momia. La religión egipcia, orientada completamente contra la muerte, hacía depender la supervivencia de la perennidad material del cuerpo. Ésta satisfacía una necesidad fundamen tal de la psicología humana: la defensa contra el tiempo. La muerte no es otra cosa que la victoria del tiempo. Fijar de forma artifi cial las apariencias carnales del ser significa arrancarlo al flujo del tiempo: reconducirlo a la vida (...)".

Esta reflexión fascinante, que impresiona por su capacidad de sintesis, ignora sin embargo dos aspectos esenciales del film: la brevedad de su vida comercial y su extrema caducidad químicofísica. Caducidad que se conoce desde los inicios, no sólo por parte del que trabaja en el cine (en las revistas corporativas de los años diez los trabajadores se lamentaban del hecho de que, a menudo, las películas, entonces inflamables, eran inservibles poco después de la proyección), sino también por cualquiera que haya hecho a lo largo de su vida una fotografía o rodado un pelicula en un formato amateur.

Desde los origenes de la fotografía, un disparo sirve para conservar un momento, para hacerlo duradero en la memoria. ¿Quién, cuando hace una fotografía, piensa que también ésta sufrirá los estragos del tiempo, perdiendo los colores hasta transformarse y requerir, para conservarla y, así, poder observarla, una restauración? El sentido común asigna a las imágenes robadas a la realidad una vida eterna a pesar de que la experiencia nos demues tre lo errónea que es esta creencia. Esta creencia ha estado tan arraigada que ha influido, durante muchísimos años, en las decisiones y comportamientos de los encargados de los trabajos, es decir, de todos aquellos que habrian debido preocuparse de asegurar un futuro a las películas producidas: los ministerios, los investigadores, las filmotecas.

Incluso para las naciones más sensibles con las políticas relaciona das con el patrimonio cultural, el reconocimiento de que el pasado del cine fuese un bien que custodiar no se tradujo en absoluto en el deber de intervenir para conservarlo, duplicarlo y restaurarlo.

La Cinémathèque française nace en 1936 en torno a un grupo de cinéfilos que miran al pasado del cine pero que también quieren intervenir en lo que está aún por hacer. Langlois y Franju son, en su actividad "filmotecaria", archiveros/criticos, comportamiento que influirá en los jóvenes que frecuentan la Cinémathèque: Godard, Truffaut, Rohmer, que ejercerán ya como cineastas en su trabajo de críticos.

No es casual que la obsesión por la conservación golpee, en el transcurso de los años treinta, en todo el mundo a jóvenes intelectuales de distinto origen. Juega un papel fundamental el mecanis- mo de la nostalgia, entendida como un sentimiento de separación y pérdida de un mundo que ha dejado de existir. Langlois y Franju, pero también durante aquellos años, en Milán, los fundadores de la Cineteca Italiana (Comencini, Lattuada, Monicelli, Mondadori) luchan solitarios contra la desaparición del mundo del cine mudo. Treinta y cinco años de arte, de historia, de sonrisas, lágrimas, de vida que el cine sonoro ha dejado atrás y destruido. Esta nostalgia, que se origina a principios de los años treinta, con el fin del cine mudo, experimenta un segundo impulso inmediatamente después del final de la Segunda Guerra Mundial. Como observa el investigador francés Pierre Nora, el temor de perder la memoria es un sen timiento que obsesiona a todo occidente de la inmediata posguerra. Los regímenes totalitarios del siglo XX revelaron la existencia de un peligro antes insospechado: la cancelación de la memoria.

\section{Las tres instancias del cine}

La naturaleza del cine es distinta respecto a la de las otras artes y en él conviven tres instancias que influyen de manera contradictoria y determinante en cada intervención de restauración.

\section{a) El cine como industria}

Cesare Brandi recuerda que "se entiende por restauración cualquier intervención destinada a restablecer la funcionalidad de un producto de la actividad humana (...) pero si se trata de una obra de arte, aunque si entre las obras de arte las hay que poseen estructurat mente un objetivo funcional (...), es evidente que el restablecimien to de la funcionalidad, si también corresponde a la intervención de restauración, representa un aspecto secundario o concomitante, nunca el primario y fundamental, que es el cuidado de la obra de arte en cuanto obra de arte."

Durante muchos años las Majors, sobretodo americanas, restablecian el valor de uso de los filmes que poseían. La Metro-GoldwinMayer distribuyó por las salas de todo el mundo, desde los años cincuenta a los sesenta, reediciones sucesivas de Gone with the wind (Lo que el viento se llevó). En cada ocasión, los negativos de nitrato originales se duplicaban con técnicas más sofisticadas, tratando de adaptar el cromatismo original a los gustos del público contemporáneo. En el transcurso de los años, los rojos y azules saturados del Technicolor se sustituyeron por tenues colores pastel. En esos momentos aún eran poquísimas las películas objeto de reimpresión y reedición. Hasta comienzos de los años setenta, una película, una vez finalizada la distribución en las salas, perdia su potencial económico. Actualmente, gracias a los pases televisivos, a los derechos de Home Video, a los distintos canales de explotación, la vida comercial de una película se ha alargado considerablemente y es potencialmente infinita.

Esto ha provocado que, tras decenios de casi total desidia, los titur lares de los derechos hayan comenzado a ocuparse de la conserva- 


\begin{tabular}{|l|}
\hline Investigación \\
Restauración \\
cinematográfica. Tierra de \\
nadie
\end{tabular}

ción y la restauración de las películas. Los titulares son todos aquellos que gozan de los derechos de explotación sobre una obra cinematográfica, como es el caso de los primeros productores de la película, aunque no sea así siempre, porque con el transcurso de los años, éstos pueden haber cedido a terceros los derechos de una obra. Si una vieja película se presenta en las salas, en videocasete o en DVD, como una versión "restaurada" el valor comercial de la operación aumenta considerablemente.

Desde hace algunas décadas, la restauración de las películas se realiza, en porcentajes cada vez más significativos, por entidades privadas que invierten dinero para recuperarlo después con las ven tas en las salas y el Home Video.

De forma cada vez más frecuente las restauraciones de los que poseen los derechos se llevan a cabo con criterios de seriedad, aprovechando los mejores materiales disponibles y con importantes medios económicos, aunque también se dan los casos menos felices, en los que las intervenciones, presentadas con gran relieve en los medios de comunicación y a escala internacional, esconden grandes alteraciones de la obra (son frecuentes las modificaciones de filtro, de los colores originales, del sonido de la época).

\section{b) El cine como arte}

Si el cine es arte o industria es una discusión que se retrotrae a sus origenes. Se han necesitado muchas décadas e innumerables esfuerzos para aceptar la idea de que una película sea un bien cut tural. El prestigio de la crítica, de la historiografia, de los autores del cine francés, y también la fuerza con que este país ha apoyado al cine, han jugado un papel determinante en esta batalla.

John Dewey señala cómo una obra de arte es recreada cada vez que se experimenta estéticamente, en caso contrario, sería materia inerte, como un cuadro en el almacén de un museo o la caja que contiene una película en una filmoteca. La restauración se considera entonces como un momento esencial para la vida de una obra. Al mismo tiempo, como recuerda Brandi, la obra de arte condiciona la restauración: "Existe un vínculo inseparable entre el proceso de restauración y la obra de arte, en cuanto la obra de arte condiciona la restauración y no al contrario." Desgraciadamente, en las pocas décadas que constituyen la his toria de la restauración, no ha sido siempre así. A menudo, también las filmotecas, a la hora de realizar una restauración, han puesto en peligro, interviniendo en las matrices, la integridad de una obra filmica. Hasta los años ochenta era una práctica habitual destruir los nitratos una vez duplicados. De forma que se des truyeron las matrices originales de muchas obras maestras que permitirían actualmente obtener duplicados de mayor calidad.

\section{c) El cine como documento}

Según Pierre Nora, desde el momento en que el pasado deja sus huellas, todo objeto puede convertirse en objeto de valor. En los últimos treinta años la idea de patrimonio se ha ido modificando, de modo que sus límites han dejado de ser estables, tienden a expandirse hasta integrar todo lo que ha sido producido. Hace treinta años poquísimos críticos abrían admitido las películas de Totò como obras que debian ser restauradas; actualmente, un número igualmente exiguo osaría a no hacerlo. El criterio del canon parece actualmente cada vez menos defendible: por tanto, es dificil decidir sobre cuáles son las obras de referencia reconocidas por la historia.

Por su propia naturaleza el cine es documental, captura jirones de realidad, momentos que nos narran, mejor que cualquier otro tipo de descripción, el clima, el gusto, el sabor de una época, de un lugar. En ningún siglo se han producido tantos acontecimientos como en el siglo veinte. Guerras, destrucciones, transformaciones narradas con gran lujo de detalles en el patrimonio cinematográfi co. Como declaraba Jacques Ledoux, durante treinta años conservador de la Cinémathèque Belge (1958-1988), cada película debe conservarse, según un principio de no selección por el que todo, tarde o temprano, puede resultar interesante. Sería conveniente recordar que una de las primeras filmotecas nació de la intuición de Albert Khan, banquero que, convertido en millonario, decidió fitmar la vida de los pueblos del mundo, creando uno de los primeros archivos cinematográficos, 149 kilómetros de película, memoria del mundo desde 1918 .

\section{El tiempo del film, el tiempo de la restauración}

Es esencial abordar ahora las complicadas cuestiones relaciona das con el tiempo del film y el tiempo de la restauración. Análisis necesario para un arte, como es el de la cinematografía, en el que, gracias a los nuevos medios de comunicación y a las nuevas tecnologias, el espectador tiene (o padece) la posibilidad de un consumo habitual y simultáneo de películas pertenecientes a épocas distintas, provocando en las obras una contracción temporal sin precedentes en el consumo de arte.

Existen distintos tiempos para una película. Está el tiempo de la producción, casi siempre ubicado de forma precisa en una época determinada. Está el tiempo de la película, que experimenta, en cambio, una perenne actualidad y que puede sufrir muchas modi ficaciones; está el tiempo del visionado, que es siempre presente; está el tiempo de la técnica, que modifica sus tecnologías; $y$, por último, está el tiempo de la restauración, que se realiza en un determinado momento y que a menudo debe contar con las posi bilidades limitadas de la reproducción.

El tiempo de la producción. En 1914, Chaplin, al inicio de su carrera, realizaba con la compañía Keystone una comedia de una o dos bobi- 
Nota: Al documental mudo Compañía española de minas del Rif (Marruecos, 1921

1930) pertenecen los fotogramas incluidos en este artículo. Han sido restaurados por la Filmoteca de Andalucia. Fuente: Filmoteca de Andalucia.

nas cada semana; después de 1930, el tiempo medio de producción de una de sus películas estaba entre los cinco y los siete años. En veintiocho años, de 1971 a 1999, Kubrick realizó cinco películas. El tiempo de producción, con frecuencia, no puede darse por concluido con la primera presentación pública de la película. Chaplin, por ejemplo, desde los años cincuenta, reintervino en muchas de sus pelícur las mudas para "actualizarlas", modificando el montaje, los subtitu los y escribiendo nuevos acompañamientos musicales para películas que había realizado hacía treinta años o más. Griffith no concluyó nunca de montar Intolerance (Intolerancia). Los ejemplos de autores que cambian (o querrian hacerlo) el montaje de sus propias pelíct las son realmente innumerables y llegan hasta nuestros días (Steven Spielberg, Ridley Scott, etc.).

Existe después el verdadero y propio tiempo de la película. Examinemos las posibles trayectorias de una obra cinematográfica. La película se concibe y se realiza. Sin embargo, si surgen problemas entre el cineasta y el productor, pueden montarse dos versiones diferentes (buena parte de la obra de Stroheim o Welles ha sufrido esta suerte). También es posible que un autor decida reintervenir en una pelicula tras la primera presentación: la versión de una película presentada en un festival a menudo es distinta de aquélla que después se proyectará en las salas. Fellini, por ejemplo, bajo la presión del productor Lombardo, redujo II bidone (La estafa) de veinte minutos tras la presentación en el festival de Venecia.

Pero supongamos que de la película exista una sola edición que se presenta ante la Comisión de censura para obtener el "nulla osta". En este momento un porcentaje bastante relevante de las obras sufre alguna intervención: el corte de algunas imágenes, la supresión de varias secuencias, la eliminación de episodios enteros. Supongamos que nuestra película supera también esta barrera. Ahora deberá contar con la distribución, que puede ser también internacional, y en cada pais se debe prever particulares pases censores. En una obra producida en época muda, las versiones nacionales diferían entre si por los diferentes subtitulos y a menudo también por el orden de los planos. En época sonora, en algu nos países, las voces de los actores se sustituyen con el doblaje; en otros, bajo la imagen aparecen los subtítulos. Tras una primera explotación en las salas, actualmente una película puede tener una emisión televisiva y reediciones posteriores, sufriendo ulteriores modificaciones.

Existen también cuestiones de carácter técnico. En época muda existían varios negativos de una misma película, con escenas rodadas por cámaras desde tomas diferentes; además todas las copias positivas, incluso las impresas por el mismo laboratorio, tenían colores y calidad fotográfica distintas. Actualmente, con la llegada del Home Video y los DVD, el número de versiones en que circula un mismo film ha aumentado aún más, sin ninguna garantía desde el punto de vista de la integridad de la obra y de lo que el usuario va a adquirir. Se puede afirmar entonces que de cada película existen distintas versiones.
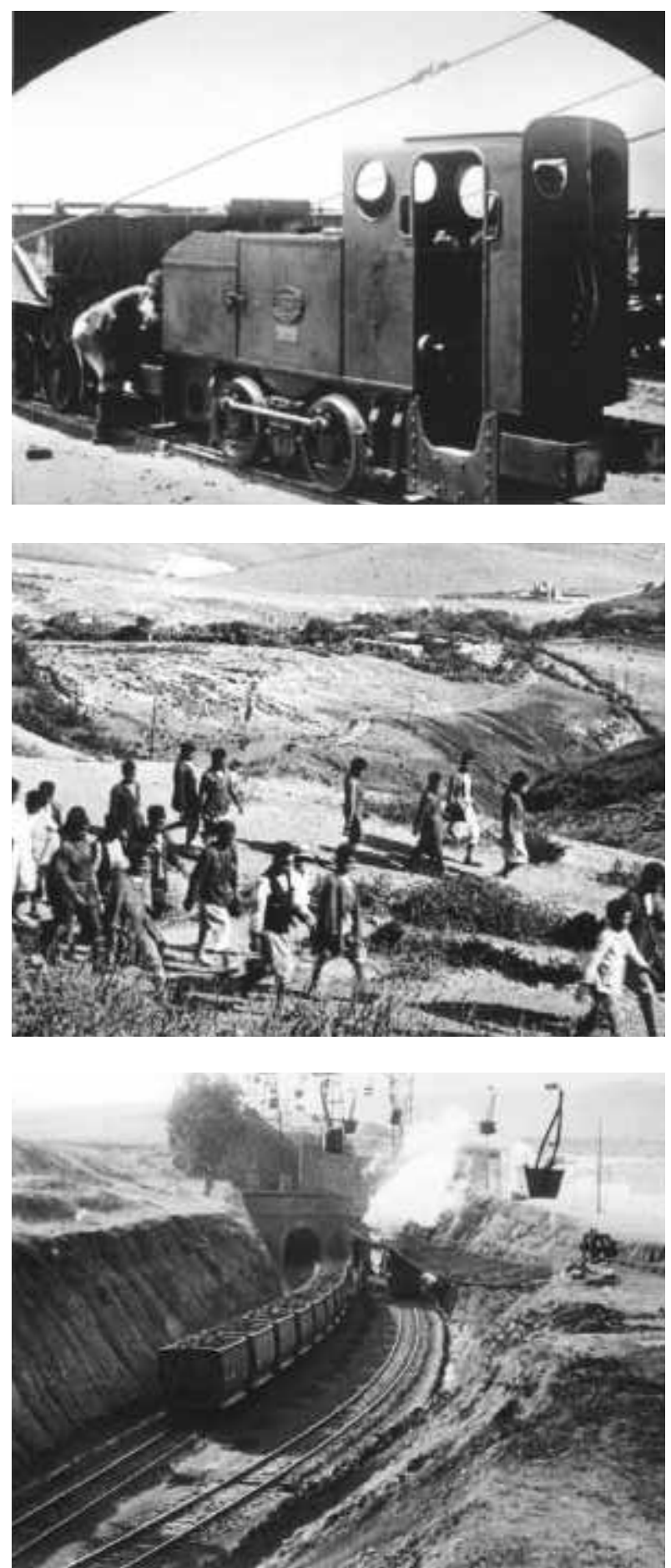


\begin{tabular}{|l|}
\hline Investigación \\
Restauración \\
cinematográfica. Tierra de \\
nadie
\end{tabular}

El tiempo del visionado es, sin embargo, un tiempo presente: para el espectador la obra vive en el momento de la proyección aunque si, cada vez más, el consumo del cine del pasado se da en un contexto de tentativas de historicidad que modifican la percepción tem poral del espectáculo cinematográfico. Además las posibilidades que ofrece el video (y aún más el DVD) de poder desmenuzar la uni dad de visión, saltando de una escena a otra, modifica profunda mente la unidad de la película.

La historia del cine avanza también en función del tiempo de la técnica. En el desarrollo de la industria cinematográfica se han modificado todos los materiales, todas las tecnologías. Muchas películas se pensaron para una tecnología que ya no existe. Una parte de los productos de los años cincuenta se han distribuido en doble versión, una estereofónica y una monofónica, o una en 3D y una normal. Pensemos, por ejemplo, en Dial M for Morder, de Hitchcock, película en la que el uso de la profundidad de campo es un momento esencial de la puesta en escena: esta pelí cula actualmente se conoce sólo en la versión en dos dimensiones. Cada vez que determinada tecnología deja de usarse todas las películas rodadas con ese sistema deben ser duplicadas en otro, lo que permite naturalmente salvarlas pero no podrá conservarse integramente la calidad y defectos del sistema precedente. Por ejemplo, tras el cierre, en 1978, del último establecimiento que utilizaba el Technicolor, los colores de aquel extraordinario sistema se perdieron irremediablemente.

Llegamos así al tiempo de la restauración, al modo en que el tiempo influye sobre la acción del restaurador. Se modifican las tecnologias disponibles (actualmente la frontera de lo digital se ha abierto, se utiliza mucho para la restauración del sonido y aún está en vía de experimentación para la imagen) pero como recuerda Nicola Mazzanti "se trabaja siempre con materiales inadecuados. En el punto actual de la tecnología y de la técnica no existen instrumentos (películas, material de duplicación, baños de revela do, procedimientos de duplicación, etc.) concebidos para la res tauración. La industria cinematográfica, y por tanto, las sociedades productoras de material sensible, no sienten la restauración como una necesidad; la actividad de duplicación de un negativo original o de un positivo se concibe sólo y exclusivamente para los materiales recientes. En términos productivos, la duplicación está y (ha estado siempre) destinada exclusivamente a la producción de duplicados de negativos con el objeto de imprimir un elevado número de copias positivas en el menor tiempo posible con el fin de saturar el mercado; nunca, en ningún caso, la conservación a largo plazo se contempla entre los objetivos inmediatos." De ahí que ninguna restauración pueda ser jamás neutra, sino que reflejará la época en la que fue realizada.

Como dice Brandi "la restauración, para erigirse como acción legítima, no deberá presumir que el tiempo sea reversible ni la abolición de la historia. La restauración, por los mismos requeri- mientos que impone el respeto de la compleja historicidad que compete a la obra de arte, no deberá ser una acción secreta o situada fuera del tiempo, sino que ha de ser considerada como evento histórico como es en sí misma, por el hecho de ser acción humana, y de inserirse en el proceso de transmisión de una obra de arte al futuro."

Por tanto, en primer lugar, deberá identificarse la versión de la pelicula que se desea restaurar, deberán recogerse todos sus elementos, filmicos y extra-filmicos, y deberán darse al espectador todas las informaciones que permitan comprender la intervención que se ha llevado a cabo.

\section{¿Quién restaura?}

Las filmotecas constituyen un universo heterogéneo de archivos que podemos identificar con la única asociación internacional, la FIAF (Fédération Internacional des Archives du Film), que cuenta actualmente con más de 120 miembros que representan a 65 países. Entre estas filmotecas existen muchas diferencias, distintas finalidades, estructuras y formas de financiación.

En los dos niveles de adhesión a la FIAF (miembros de pleno título y asociados), archivos que consagran gran parte de su presupuesto a la conservación y a la restauración del patrimonio coexisten con instituciones que se dedican casi exclusivamente a la difusión de la cultura cinematográfica, como los museos y bibliotecas cinematográficas.

Si intentamos reagrupar los más de 120 archivos en grupos homogéneos, podemos identificar cuatro subgrupos. Los grandes archivos nacionales, que ejecutan exclusivamente una actividad de conservación y restauración: todos los grandes países occidentales y todos los paises del ex-área comunista tienen archivos de este tipo, distintos según la dimensión de su colección, la magnitud del pre supuesto, el número de empleados, la fecha de entrada en la FIAF, pero idénticos en finalidad y estructura. En general, todos los grandes archivos nacionales de este tipo padecen las mismas limitaciones. La profunda distancia existente entre la actividad de conservación y la de presentación priva a estas estructuras, a menudo mastodónticas y aquejadas de una pesada burocratización, de la confrontación con el público de una sala cinematográfica. Toda la actividad de estos archivos corre el riesgo de finalizar en sí mismos. Una película se selecciona y restaura no para ser mostrada, para confrontarla con un determinado público, sino para ser conservada. Si algún programador externo la eligiera, la película sería mostrada, pero como activad ajena al archivo, que por tanto trabaja para un futuro abstracto. Esta lógica, que desde muchos aspectos parece monstruosa, tiene para el campo de la restauración una implicación muy grave: provoca que estas estructuras sean impermeables a los estímulos derivados de la confrontación con el trabajo de los 
otros archivos, lo que tiene como resultado que las competencias del personal de estas instituciones resulten seriamente dañadas, problema muy grave para un sector joven como es el de la restau ración que está experimentando años de gran transformación tecnológica y metodológica. De todos modos, en todos estos archivos, la parte más relevante del presupuesto se dedica a la conservación más que a la restauración. La vastedad de las colecciones requiere enormes inversiones para la construcción de depósitos climatizados adaptados para las labores de transporte, catalogación y gestión de los materiales fílmicos.

Normalmente estos archivos disponen de su propio laboratorio equi pado para la duplicación analógica. Sin embargo, confían la mayor parte de las intervenciones de restauración a laboratorios privados externos. El personal encargado del control de la calidad verifica tanto las duplicaciones y las restauraciones realizadas internamente, como las que se realizan en el exterior reenviando a los laboratorios los resultados valorados insatisfactorios.

El segundo subgrupo son aquellos archivos filmotecas y filmmu seum) que, junto a la actividad de conservación del cine (no sólo de películas, sino también de fotografías, carteles, libros, revistas), llevan a cabo una labor permanente de presentación y, por tanto, se encargan de la programación de al menos una sala, que normalmente es de su propiedad. Estos archivos, aunque no dependan directamente de la estructura de Estado, como es el caso de la Cinémathèque Française, reciben de éste relevantes fondos. Sus colecciones com prenden tanto películas nacionales como extranjeras. Por tanto, su actividad de restauración no contempla sólo el patrimonio nacional, sino que prioriza las necesidades de la colección.

Estas filmotecas pueden tener laboratorios propios, como la Cinémathèque Royale de Belgique, pero la mayor parte de las veces llevan a cabo las intervenciones de duplicación desde laboratorios privados, con los que colaboran estrechamente para lograr mejoras cualitativas, produciéndose así una dialéctica cliente-proveedor enriquecedora y compleja. Por ejemplo, gracias a la colaboración entre Nederland Filmmuseum, el archivo del Estado holandés, y el laboratorio privado Haghefilm se han alcanzado en los años ochen ta y noventa unos resultados tan interesantes que han influido en la labor de restauración de muchos otros archivos.

Existen, además, y están experimentando un fuerte crecimiento, los archivos locales que, junto a la labor de presentación, conservan el patrimonio de una comunidad regional o local. En los últimos años han surgido archivos vascos, catalanes, corsos, escoceses, galeses, sardos, macedonios... estas instituciones son como archivos de Estado en miniatura.

La cuarta categoría se compone de los museos y de las colecciones no filmicas: para muchos de los socios fundadores de la FIAF estaba claro que el objetivo de una filmoteca era conservar la memoria del cine: pero no sólo de las películas, sino también de todo el sistema de soportes documentales y tecnológicos que precede, sigue y acompaña a la realización de una película. Escenificación, diarios de trabajo, fotografías, manifiestos, bocetos, folletos, revistas, libros, vestuario, escenografía, maquinaria de los estudios y de los cinematógrafos, se conservan así en departamen tos expresamente diseñados de muchos archivos.

La relevancia de estos materiales ha otorgado en ocasiones a estos fondos la condición de instituciones autónomas. Es el caso, por ejemplo, de la BiFi, la gran biblioteca francesa auspiciada por el Ministro de Cultura Jack Lang que reunió los principales fondos y patrimonios cinematográficos documentales parisinos, y también del Archivo de la Academy Awards en Beverly Hills que consta de los fondos documentales de la institución que otorga anualmente los Oscar.

Mención aparte merecen los museos que coleccionan y exponen los aparatos tecnológicos como el Museo Nazionale del Cinema de Turín que posee, probablemente, la mayor colección precinematográfica existente.

La fundación de la FIAF, que data del 17 de junio de 1938, incluye una claúsula que será esencial en toda su historia, verdadera frontera entre los socios de la Federación y los otros: "Están rigurosamente excluidas de la federación todas aquellas instituciones $u$ organizaciones que utilicen sus películas con fines comerciales." Por último, fuera de la FIAF existen dos grandes categorías de archi vos para las imágenes en movimiento: los archivos televisivos y los archivos de los propietarios de los derechos. Los primeros cuentan a menudo con notables colecciones de películas y, a partir de los años setenta, se han convertido en productores de una cuota relevante de cine de calidad, sobre todo en Europa. Como es el caso concreto del papel que en los años noventa ha tenido Canal Plus en el desarrollo del cine de calidad europeo. Los segundos están presentes en Europa y en Estados Unidos, y desde los años nover ta han comenzado a realizar, con distinta intensidad, proyectos de restauración de manera independiente. De la Gaumont al Instituto Luce, de la Murnau Stiftung a la Sony Columbia, quizás todos los archivos que gestionan derechos de explotación poseen departamentos dedicados a la restauración.

Figuras importantes, aunque sean casos aislados, son la Lobster Film, compañia privada francesa pequeña y dinámica que gracias a las ventas que realiza a las televisiones cada año consigue restaut rar un cierto número de películas, sobre todo mudas, y el caso de la Film Foundation que, bajo la prestigiosa dirección de Martin Scorsese, ha reunido algunos de los más famosos directores americanos para salvar películas en peligro de desaparecer. Scorsese, que también es uno de los mayores coleccionistas de películas norteamericanas, ha resucitado películas que amaba y que se encontraban en condiciones preocupantes para los cinéfilos. En concre- 


\begin{tabular}{|l|}
\hline Investigación \\
Restauración \\
cinematográfica. Tierra de \\
nadie
\end{tabular}

to, destacan las restauraciones de Johnny Guitar (Nicholas Ray, 1954) y Pursued (Raoul Walsh, 1947), con las que se ha podido volver a disfrutar de estas dos películas en las salas de todo el mundo, relegadas hasta entonces sólo al pase televisivo.

En los últimos quince años hemos presenciado también la implicación de algunas televisiones europeas en la restauración, como es el caso de la cadena inglesa Thames Televisión, que inició una larga, y ahora desgraciadamente conclusa, colaboración con Kevin Brownlow y David Gill. El trabajo de los dos historiadores ha permi tido que los cinéfilos de medio mundo puedan volver a visionar clásicos del cine mudo en versiones brillantes. En el panorama televisivo europeo un papel de primer orden para la difusión del cine mudo a través de versiones restauradas lo ha tenido el canal franco-alemán Arte, que cada mes programa en la franja horaria que sigue al prime time un film mudo restaurado y acompañado de música compuesta para la ocasión.

Recientemente han aparecido nuevos actores en el campo de la restauración: Ios editores de DVD, que desarrollan una función bastante importante facilitando a un público amplio clásicos de la historia del cine en versión original. Muchas ediciones en DVD americanas destacan por la calidad del producto fomentando en el público contemporáneo la demanda de cine antiguo. Gracias al trabajo de Criterion, Ripley, Kino Internacional, actualmente ningún cinéfilo consideraría que las viejas copias de $16 \mathrm{~mm}$ fuesen la única fuente de acceso privilegiado a las películas de la historia del cine (cosa que sí sucedia inevitablemente hasta los años ochenta).

Es necesario recordar que las televisiones y los editores de DVD, así como buena parte de los propietarios de los derechos, no realizan el trabajo de conservación, es decir, por norma no se ocut pan, como sí hacen en cambio las filmotecas, de invertir dinero en realizar, para cada película, nuevas matrices de $35 \mathrm{~mm}$ destinadas a su preservación. Lo que se hace es un máster digital sobre el que se ejecutan los trabajos: lo que significa que el futtr ro no está asegurado, porque hasta el momento el soporte que garantiza a la película una mayor duración, y sobre todo la continuidad de los materiales originales, es la película de $35 \mathrm{~mm}$. Existe otro elemento que introducen las televisiones y los editores de DVD: la exigencia de una calidad de imagen que respete los estándares televisivos. Quien se ocupa de la emisión televisiva está convencido de que el público no acepta las señas del tiem po presentes en una película. Por tanto, cada huella de decaden cia (rayas, reducción de definición de la imagen o del sonido) debe ser limpiada y corregida, para lograr una imagen homogénea y perfecta que elimine las huellas del tiempo del film. Esta filosofía de limpieza de la imagen arriesga con imponer un estándar incluso en la restauración que llevan a cabo las filmotecas, que si quieren cubrir una parte de los costes, no pueden prescindir del pase televisivo de sus obras restauradas.
Por otro lado, es evidente que la integridad estética de una película del pasado supone unas características tecnológicas distintas respecto al estándar moderno. Es indudable que las tomas de algunas peliculas neorrealistas, que no podian ser dobladas porque no funciona ban los estudios de doblaje, parados por el conflicto mundial, sea aún un elemento esencial para la veracidad de aquellas películas.

\section{El cine como arte de la destrucción}

No existen leyes que obliguen a los productores a depositar las películas 0 , si existen, afectan sólo a algunas naciones, no son retroactivas y se limitan normalmente a prescribir el depósito de una copia positiva. Las películas tienen una vida comercial infinita desde hace sólo pocos años, pero, durante más de setenta años, del futuro del cine se han ocupado sólo las filmotecas. Por otra parte, la destrucción ha sido una práctica habitual en la historia del arte. Basta pensar en la destrucción masiva perpetrada en las iglesias románicas y barrocas.

Cada vez que se proyecta una película, se acelera su muerte. Cada proyección incide en su soporte modificándolo. El espectáculo en que consiste la vida de este arte determina también su disolución.

Cuántas veces los responsables de un archivo se han preguntado si es conveniente mostrar una copia, a riesgo de dañarla, y no mejor conservarla guardada en una caja hasta el momento en que estén disponibles los medios para restaurarla; siendo conscientes de que, de todos modos, aunque se conserve de la mejor manera posible, avanzará el proceso de degradación de la película. Pero examinemos las causas de destrucción:

\section{Proyecciones}

La invención de Los Lumière prevé un momento de gran fragilidad mecánica, la proyección. Es el momento en el que se acumula suciedad y grasa sobre la película, lo que provoca el aumento y profundidad de las líneas sobre el soporte y la emulsión. Las perforaciones pueden ser reforzadas hasta provocar que la copia sea improyectable, quizás llena de cortes y fracturas, y por tanto, de reparaciones que aumentan el riesgo de roturas y la pérdida de fotogramas. El número de pases que una copia positiva puede soportar es por tanto limitado.

\section{Decadencia química y física}

\section{Los soportes}

$>$ El nitrato de celulosa, soporte sobre el que se ha grabado gran parte del cine producido por Edison hasta 1951, es un material de gran inestabilidad. Su degradación comienza en el mismo momento en que se produce. Ya en la época muda se dieron cuenta de los problemas que el soporte de nitrato causaba. Todos los laboratorios debian contar, ya en los años diez, con este mate- 
rial que tiende, cediendo la humedad, a contraerse y a perder su paso original. Su degradación es imparable: se puede ralentizar pero no parar. Tarde o temprano todo el cine en "nitrato" se trans forma en un polvo amarillento altamente inflamable. La historia del cine está repleta de incendios que han masacrado centenales de millares de bobinas. Desde el incendio en el Bazar de la Charité en mayo de 1896, en el que perecieron ciento cuarenta personas, hasta el incendio de 1980 de Pontel en el que se perdieron 200.000 cajas coleccionadas por Henri Langlois. En medio, decenas de incendios de laboratorios y archivos: desde Roma (el último incendio en la Cineteca Nacional en 1985) hasta San Paolo (los depósitos de la Cinemateca se queman en dos ocasiones, en 1957 y en 1969, destruyendo el 40\% del material conservado). Desde Buenos Aires (los depósitos de casi todos los laboratorios argentinos han sido golpeados por las llamas) hasta Estocolmo (1941, se devastan los depósitos de la Svensk Filmindustri). Desde Tokyo (1984, Japan Film Center, 300 titulos) a Ciudad de Méjico (en 1982 centenares de películas conservadas de la Cinemateca Mejicana).

> El triacetato. 1951 ha estado por mucho tiempo considerado por todos los archiveros del mundo como el año de la salvación. A partir de aquel año los principales productores de película cinematográfica introducen en el mercado el soporte de triacetato, la denominada película de seguridad por no quemarse y ser, según sus productores, estable. El hechizo dura una treintena de años, hasta cuando en los depósitos de todo el mundo comienza a afincarse una nueva enfermedad, el Vinegar Syndrome: el triacetato decae a causa de la pérdida de un componente, el ácido acético. Muchísimas películas, incluso algunas recientes e importantes, padecen este terrible sindrome.

La degradación del color

El cine ha tenido muchos sistemas de color desde sus comienzos. Todos los sistemas de grabación usados hasta 1952 poseian una fuerte estabilidad de los colorantes. El sistema Eastmancolor introducido en el mercado ese mismo año sustituyó, gracias a su forma simple de utilización, a todos los sistemas anteriores.

Desde 1982, gracias a la campaña promovida por Martin Scorsese, se ha hecho evidente lo que hacía años estaba bajo los ojos de todos: el sistema Eastmancolor es víctima de una fuerte degradación que transforma las copias positivas en monocromías rojas. El problema es menos grave en los materiales negativos, dotados de copulantes más estables, pero que sin embargo, en distinta medida, según como hayan sido fabricados y conservados, pierden sus colores originales.

Nuestra memoria recuerda con particular fuerza y precisión los colores de nuestro pasado. Cuando vemos una película de Marilyn Monroe, la diva del Technicolor, en el que los colores son pálidos y ya no tienen la saturación brillante de los años 50 , comparamos con el color que recordamos o creemos recordar. Nuestra interpre- tación, nuestra "comparación natural", no aparece siempre con las imágenes. Más dificil resulta aún si vemos la versión de una película en la que faltan secuencias completas, experiencia que la televisión italiana (incluidas RAl y Mediaset) lleva a cabo continuamente sin que nadie se atreva a intervenir.

\section{"Estructura" industrial del arte cinematográfico y la desaparición de las películas}

Desde el momento en que una película deja de distribuirse en las salas, pierde su interés productivo y desaparece como film, película cinematográfica, iniciando una nueva vida, televisiva, mag nética, digital.

Como decía, no existe, aparte del depósito legal (que no existe en todos los paises), leyes internacionales que obliguen a los productores a depositar sus películas en un archivo. Todo depende de las leyes emanadas en cada estado en cuestión. El panorama general parece, en cambio, desconsolador, basado más en acuerdos locales entre un archivo y los titulares de los derechos que en verdaderas políticas nacionales orientadas a la salvaguarda del patrimonio cinematográfico.

Si queremos leer una obra de un maestro de la literatura, podemos encontrarla fácilmente en una librería o en una biblioteca; si queremos ver la obra de un maestro de la pintura, debemos esperar a que se organice una muestra antológica o adquirir una obra monográfica dedicada al artista. Si queremos ver la obra de Gance o de Lubitsch, de Ford o de Vidor, enloquecemos. Si nos contentamos con el videocasete o el DVD, podremos encontrar sólo algunas. Descubriremos que una parte de su obra se ha perdido, que de lo que ha sobrevivido, algunas sólo se pueden reproducir en versión de $16 \mathrm{~mm}$ y lejos de su esplendor original, que algunos materiales están en manos de los que poseen los derechos que no conceden su copia para proyectarse en una sala. El patrimonio cinematográfico aparece así como un continente inaccesible que, lentamente, se está alejando de sus espectadores.

\section{Los periodos de destrucción}

Si intentamos subdividir la historia del cine en etapas que correspondan a los distintos periodos de destrucción del patrimonio no podemos dejar de hacer referencia al trabajo de Raymond Borde que, por vez primera, recogió en su libro Les Cinémathèques el trabajo de años, intuyendo las regiones y los periodos en que se produjeron las pérdidas.

Actualmente es posible poner al dia este trabajo esencial gracias a los estudios más recientes en los que se distinguen cinco periodos bien distintos: 


\begin{tabular}{|l|}
\hline Investigación \\
Restauración \\
cinematográfica. Tierra de \\
nadie
\end{tabular}

$>$ Los orígenes. De este periodo, contrariamente a lo que se puede pensar, se conserva una parte muy relevante y significativa. En concreto, la política puesta en marcha desde finales de los años 80 en Francia ha permitido, gracias a la labor de los archivos franceses, la casi completa restauración de las obras conservadas. Incluso de un autor maldito como Méliès (activo entre 1896 y 1912), constreñido, en 1923, a destruir por desesperación los negativos de parte de sus películas, ha sobrevivido más del $30 \%$ de su obra.

> Desde 1900 a 1913 es el periodo de las grandes pérdidas. En términos mundiales se calcula que el $75 \%$ de patrimonio se haya perdido. Sin embargo, la situación es muy desigual y diferente de una nación a otra, sobre todo respecto de una casa de producción a otra: películas de la Gaumont, de la Pathé, de la Cines y de la Vitagraph, y en una porcentaje más reducido, de Ambrosio y de Eclair, Itala y Messter, Nordisk y American Miograph se han conservado en todos los archivos del mundo.

Si actualmente es posible tener una idea más clara sobre la producción de aquellos años se debe al hecho de que han sobrevivido colec ciones de la época muda procedentes de países geográficamente alejados entre sí. Entre todas las colecciones, destaca Desmet, que toma el nombre del distribuidor y comerciante holandés que realizó la colección y cuyos herederos la donaron en 1959 al Nederlands Filmmuseum. Una colección riquísima, que contiene las mejores producciones francesas, alemanas, danesas, americanas e italianas realizadas entre 1910 y 1916; la colección consta además de fotografias, manifiestos, publicaciones, programas y, sobre todo, de cartas que permiten reconstruir la actividad de este distribuidor.

> Las pérdidas del periodo que va de 1913 a la llegada del sonoro se calculan en torno al $65 \%$. La llegada del largometraje reduce la cantidad de títulos producidos y obliga a la estructura productiva a dotarse de instalaciones industriales. Aparecen en el mercado, conquistándolo inmediatamente, las Majors americanas que han sobrevivido hasta hoy, conservando buena parte de lo que han producido. Sin embargo, las mayores pérdidas se concentran en grandes nombres: películas de Lang, Lubitsch, Murnau, Paul Leni, Joe May, Camerini, Blasetti, Delluc, Dulac, Feyder, Duvidier, Epstein, Gance, Stiller, Sjöstrom, Christensen, Hitchcok, Griffith, Sternberg, Stroheim.

$>$ La pérdidas del periodo de los años 30 al los años 50 se reducen considerablemente. En torno al 20\%, del 30 al 39, y un 10\%, entre el año 40 y 49. La creación de las filmotecas a partir de mediados de los años 30 limita la hemorragia de las destrucciones. Al mismo tiempo, al tomarse una conciencia de la validez artística del cinematógrafo, cuestión antes debatida sólo en los círculos elitistas, pero convertida después en patrimonio cada vez de mayores proporciones, ha hecho que sólo en casos debidos a factores externos, acontecimientos bélicos sobre todo, pero también debido a las diffciles condiciones de conservación, se hayan lamentado pérdidas considerables de películas.
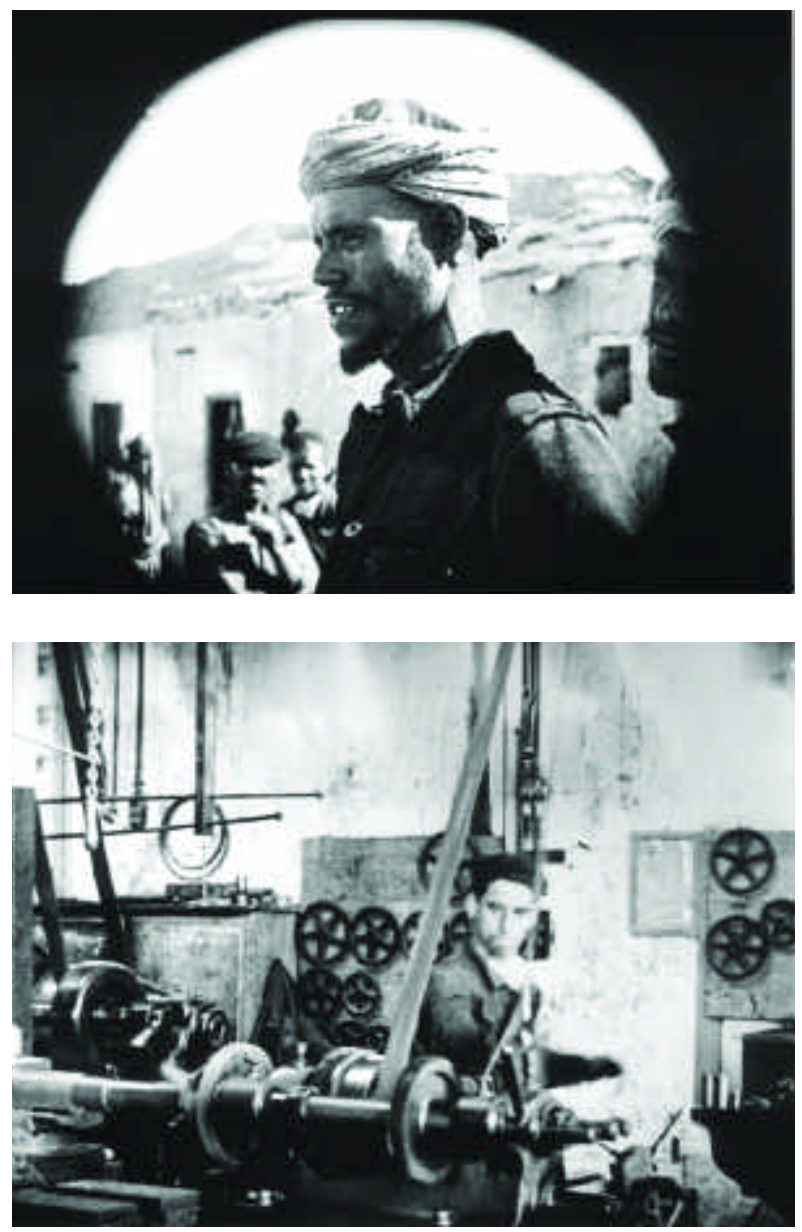

Aparte de la pérdida de una larga lista de películas realizadas en Inglaterra entre 1931 y 1936 por Powel y Pressburger, los conflictos bélicos causaron la destrucción de películas realizadas durante la guerra civil española, así como en los últimos años del fascismo italiano, en el periodo de Vichy en Francia, mientras que la debilidad químico-física de la película y los ya citados incendios que han devastado archivos y laboratorios públicos y privados han sido la causa de ulteriores erosiones del patrimonio fílmico.

Sin embargo, son sobretodo las películas realizadas por pequeñas productoras independientes las que arriesgan a desaparecer más que ninguna otra.

> Desde 1952 hasta nuestros dias, con la llegada de la televisión, se modifica la vida comercial de una película. Actualmente pocos productores destruirían los negativos o perderian todas las copias de una película de su propiedad. Y sin embargo los riesgos de pér- 
didas aún son significativos. A partir de la llegada del sonoro, desde los primeros Vitaphone hasta hoy, la industria cinematográfica ha sufrido tantas transformaciones técnicas que podrían cancelar del mercado decenas de invenciones.

Una atención aparte merecen dos grandes producciones naciona les, la japonesa y la india, que han perdido casi todo su trabajo hasta la segunda guerra mundial: sólo el $5 \%$ de su producción parece haber sobrevivido.

\section{Catálogos no homogéneos, catálogos que "no se hablan"}

Para llevar a cabo la restauración de una película, uno de los primeros pasos que es necesario emprender consiste en una búsqueda a conciencia de los mejores materiales existentes en un amplio radio: el cine se convirtió inmediatamente en un arte internacional, la mejor copia que sobrevive de una obra podría encontrarse muy lejos del lugar donde la película fue producida. Muchas películas mudas italianas, consideradas perdidas, se han encontrado en Brasil, donde había una gran comunidad italiana aficionada a ver las peliculas producidas en la patria. Las mejores copias de muchos clási cos de mudo se han encontrado en Montevideo, donde un poeta amaba coleccionar lo mejor de lo que se había producido en Europa. La copia más completa de la primera comedia de Chaplin se encontró en Belgrado. A menudo se puede encontrar posteriormente un elemento que contiene información y de una calidad de la que carece el material que se conoce: una escena censurada, un montaje distinto, un mejor estado del sonido y del color.

Estas investigaciones pueden durar años, porque además los catálogos de las filmotecas y de los titulares de los derechos están muy incompletos (casi ninguno ha catalogado todo lo que conserva) y contienen descripciones imprecisas (pocas informaciones y de carácter vago que no ofrecen una idea de la riqueza del material conservado). El mejor modo de conocer un material es yendo a verlo personalmente o hacer que nos lo envien, lo que supone un incremento de los costes y una prolongación en el tiempo.

\section{¿Qué películas restaurar?}

El problema es siempre el financiero. El coste de restauración de un largometraje oscila entre los 15.000 y los 75.000 euros: una bonita cifra tanto para las instituciones públicas como para las privadas, que deben por tanto seleccionar algunos títulos entre sus vastísimas colecciones.

Los criterios básicos a partir de los cuales un archivo selecciona una película y no otra para su restauración varían según el tipo de institución. Un archivo regional restaurará una película que pertenece a su patrimonio; un archivo privado buscará la película que puede asegurarle mayores beneficios.

Desde hace mucho tiempo las filmotecas que integran la FIAF tratan de encontrar principios comunes que regulen a nivel mundial el criterio de selección de los títulos que se deben restaurar.

El único criterio que está bastante difundido y que se reconoce a nivel internacional es que cada archivo restaure las películas de su país. Este criterio ha permitido concentrar más los esfuerzos, pero no resuelve algunas cuestiones problemáticas derivadas de una división tan simple del trabajo de restauración: los archivos acumur lan colecciones que tienen su propia lógica interna, y por tanto, si al fondo de un determinado archivo pertenecen películas de nacionalidad distinta respecto a la del archivo, y por tanto conservadas en otros países, es lógico y oportuno restaurarlas para poder estur diar posteriormente la colección de manera integra. Por otro lado, no podemos olvidar que a menudo dos copias de la misma pelícur la son muy distintas entre ellas.

De todos modos, que una colección deba ser reimpresa y estudia da en su integridad transnacional es un principio aceptado de forma casi unánime actualmente. Sólo los archivos de estado, por motivos dictados por las políticas ministeriales, continúan restau rando únicamente películas nacionales, pero este principio está cada vez más superado.

\section{Más allá de la nacionalidad, otros criterios}

Con el aumento de las colecciones conservadas y la cantidad de películas que duplicar, los archivos han tratado de encontrar una serie de principios objetivos que permitiesen establecer de forma automática prioridades para restaurar.

Dos criterios, junto a la prioridad de las películas nacionales de la que ya se ha hablado, han terminado por asumir un relieve particular: el estado de conservación y la singularidad de los materiales. Una película que se está descomponiendo y que probablemente es una copia única debe ser reimpresa inmediatamente; si el archivo que la posee no tiene la capacidad de hacerlo, puede requerir la ayuda de otras filmotecas de la FIAF.

Otros criterios tienen origenes histórico-estéticos. La celebridad de un título, que sea reconocido como un clásico de la historia del cine, aumenta las probabilidades de restauración. Al contrario, una película no identificada, de la que no se conozca ni siquiera el autor, rara vez se reimprime. Los programas de compilación (Bits and Pieces) llevados a cabo por Nederlands Filmmuseum han significado un punto de ruptura respecto a esta actitud, poniendo de relieve el valor estético que pueden tener también las películas y fragmentos no identificados. 


\begin{tabular}{|l|}
\hline Investigación \\
Restauración \\
cinematográfica. Tierra de \\
nadie
\end{tabular}

Un papel decisivo en la transformación de las prioridades de restau ración de los archivos lo han jugado también los festivales especializados como Le Giornate del Cinema Muto e II Cinema Ritrovato. La atención que prestan estas manifestaciones a las partes más inexploradas de la historia del cine ha impulsado a muchos archi vos a intervenir en materiales que, hasta hace pocos años, no habrían sido nunca reimpresos.

Como ya hemos señalado, la categoría a menudo usada para justificar la elección de un trabajo de restauración era la de "colección". A menur do en un archivo existen fondos que tienen una lógica intrínseca: las películas recogidas por un coleccionista según determinados criterios, las películas depositadas por un productor, un cineasta, un actor 0 actriz... De ahí que una filmoteca elija reimprimir varios títulos que adquieren mayor interés que un titulo si se presenta de forma aislada.

Un ejemplo paradigmático es la política de la Cinémathèque française que, después de una larga batalla con el Centre Nationale de la Cinémathographie, ha visto en parte reconocido su posiciona miento: reimprimir no sólo las películas francesas, sino todas las películas coleccionadas por Langlois; el hecho de que se trate de obras reunidas en Francia las convierte en patrimonio nacional que como tal debe ser salvaguardado.

Junto a estos criterios existen, evidentemente, criterios económicos En un archivo que cuenta con un presupuesto sólido podrán coexistir varios criterios de restauración, mientras que otro con menos recursos deberá seleccionar más afinadamente sus intervenciones. De la misma forma, proyectos de restauración particularmente costosos serán imposibles de realizar en ciertos archivos: es el caso de la reimpresión de una película a partir de las tres matrices Technicolor que es un lujo que pocas filmotecas del mundo se pueden permitir.

Por último, es necesario subrayar el motivo principal por el que siempre una filmoteca se lanza en un proyecto de restauración: la posi bilidad de establecer un acuerdo con un propietario de los derechos que participe en los gastos o que conceda a la filmoteca la posibilidad de utilizar la película una vez que haya sido restaurada. Cada vez es más frecuente que los productores de DVD participen en proyectos de restauración, financiando una parte a cambio de tener acceso a los materiales para realizar un máster de alta calidad.

\section{Cómo se restaura. Cómo ha evolucionado la disciplina de restauración desde la posguerra hasta nuestros días}

Al inicio, en los años 50, la idea de restauración hacía referencia al conjunto de operaciones que permitía reestablecer la funcionalidad de una obra, sobre todo de las películas mudas. Henri Langlois reimpresionaba las películas de las que sólo tenía los negativos de nitra- to con el fin de poder mostrarlas, sin preocuparse de que los negativos en la época muda a menudo no tenían los subtítulos, que se introducian directamente en las copias positivas, como tampoco contenían los procedimientos de imbibición y viraje (que también se realizaban posteriormente sobre los positivos).

Sin embargo, muy pronto, junto a la exigencia de mostrar las copias raras de las películas del pasado, se toma conciencia de que el objetivo de las filmotecas es también y sobre todo el de conservar las obras, por tanto crear las condiciones y materiales de conservación que puedan ser transmitidos en el futuro. En el seno de la FIAF se desarrolla justo en estos años un encendido debate entre dos visiones contrapuestas existentes en las políticas de las filmotecas: Langlois insiste sobre la necesidad de exhibir el patrimonio a cualquier coste, porque la epifanía del cine se encuentra en la proyección; en sentido contrario, Lindgren sostiene que el objetivo prioritario de las filmotecas es la conservación de las imágenes en movimiento (si de una película existe solamente una copia, ésta no debe proyectarse).

Las primeras reconstrucciones llevadas a cabo por las filmotecas recuerdan mucho a la postura de Viollet Le Duc en la restauración arquitectónica. En esta línea está el trabajo del crítico e historiador de cine Joseph-Marie Lo Duca, co-fundador y redactor hasta 1954 de "Cahiers du Cinéma" (que posteriormente fue sustituido por Eric Rohmer), sobre La Passion de Jeanne d'Arc, de Dreyer, film mítico y del que se consideraba perdida la versión original hasta los años ochenta. Lo Duca decide retocar arbitrariamente la película en 1952, modificando radicalmente el montaje del director danés (que protestó enérgicamente) e introdujo subtítulos y música postiza. De forma más reciente, una de las múltiples restauraciones realizadas sobre L'Atalante de Jean Vigo se ha llevado a cabo montando en la versión restaurada los encuadres desechados por el propio director, traicionando de esta forma las decisiones del autor de la obra.

Con el paso de los años ha comenzado a desarrollarse una mayor conciencia crítica en relación con el patrimonio cinematográfico y se han emprendido, a partir de los años 70, trabajos de reconstrucción que han permitido reflexionar de manera más compleja en torno al concepto de restauración aplicado al cine. Las legendarias restauraciones de Napoléon de Abel Gance y de Metropolis de Fritz Lang contribuyeron de manera crucial al desarrollo de la disciplina de restauración. Se trata de dos trabajos de restauración vinculados indisolublemente a dos historiadores del cine, Kevin Brownlow y Enno Patalas, que ha dedicado toda su vida a la reconstrucción de estas dos películas. La reconstrucción de Napoléon, por Brownlow, ha supuesto investigaciones larguísimas en filmotecas y con coleccionistas de todo el mundo, además del estudio de copias supervivientes en diferentes formatos (35 mm, $16 \mathrm{~mm}, 9$ '5 mm, $8 \mathrm{~mm}$ ), un trabajo que culminó con la recuperación del episodio de la infancia de Napoleón en Brienne y con el reestablecimiento de tres fotogramas de las 
secuencias finales. Patalas, durante años director de la Cineteca municipal de Munich, que tuvo un papel de primer orden en la recuperación del cine mudo alemán, tuvo el gran mérito de demostrar la importancia del estudio de las fuentes extra-filmicas en el proceso de restauración (la censura, el guión y la escenifi cación original, etc.), y la investigación llevada a cabo para la reconstrucción de Metropolis ha abierto el camino a un nuevo modo de abordar la restauración.

De gran importancia ha sido también el monumental trabajo de reconstrucción de Intolerance, llevado a cabo por el Museum of Modern Art de Nueva York a finales de los años 80. Desde el 5 de septiembre de 1916, fecha de presentación de la película en el Liberty Theater de Nueva York, hasta su muerte, Griffith no ha dejado nunca de intervenir en su propia película modificándola en cada proyección. El trabajo (hipotético) de reconstrucción del editio princeps 0 , en otras palabras, de la primera versión montada por Griffith, se basó principalmente, más que en las copias ya conocidas, en el estudio de 2.203 fotogramas que contenian cada encuadre y subtítulos depositados por el director en la Library of Congress pocos meses antes de la presentación (una especie de depósito legal para defenderse de las falsificaciones), en una lista de los subtitulos depositada en la UCLA por el asistente de montaje, en la partitura para orquesta y para piano y en la recuperación, gracias al Danske Film Institute de Copenhague, de una copia de la época de la que hasta ese momento se ignoraba su existencia. La reconstrucción de la película ha implicado largas confrontaciones entre los distintos materiales (heterogéneos entre si); alli donde faltaban los encuadres se ha recurrido al uso de los freeze-frames, es decir, se ha mantenido la imagen de los fotogramas depositados en la Library of Congress durante el tiempo previsto por la partitura musical. Según los mismos encargados de la restauración (Peter Williamson, Gillian B. Anderson, Paul C. Spehr y Hielen Bowser) la versión reconstruida de Intolerance es hipotética, es decir, existe el riesgo de que no haya nunca existido (siendo la película de Griffith una obra que no ha sido nunca "cristalizada" de una manera única), pero era la única que se podía obtener a partir de los materiales disponibles, según un método filológico e historiográfico coherente.

La época de los "pioneros de la restauración" ha permitido de manera del todo natural el nacimiento dentro de las filmotecas de una verdadera actividad de restauración y la creación de laboratorios (o de estrechas colaboraciones con ellos). Los laboratorios son de dos tipos: comerciales, con un sector dedicado a los trabajos especializados (HagheFilm, Centrelmage, StudioCine, etc.) o aquellos exclusivamente dedicados a los trabajos de restauración. Entre estos últimos, merecen especial atención, en el ámbito europeo, L'Immagine Ritrovata de Bolonia, y los laboratorios de la Cinémathèque Royale de Bélgica y de la Nacional Film and Televisión Archive (Londres), que han sabido encontrar nuevos métodos (DesmetColor) y desarrollar prácticas de restauración que se adaptasen a los múltiples formatos del cine (por ejemplo, los $28 \mathrm{~mm}$ ) y a las distintas técnicas usadas en más de cien años de historia (el Kinemacolor).

El proceso de restauración no se agota con el establecimiento de materiales más resistentes a las inclemencias del tiempo, sino que se convierte en un proceso que permite conocer mejor la obra que se está restaurando. Deber del restaurador es el de "entregar" a los estudiosos e investigadores las películas en sus versiones correctas. El estudio de las coloraciones del cine mudo (a mano, con la técnica del pochoir, imbibiciones, virajes) se erige quizás en la batalla más grande encabezada por las filmotecas de todo el mundo para demostrar que el cine mudo no era en blanco y negro. Un papel pionero en este campo ha sido desempeñado en los años ochenta por el Filmmuseum de Ámsterdam que se empeñó en restaurar su colección, única en el mundo, de películas de principio de siglo conservando las coloraciones originales y encabezando una campaña de sensibilización sobre este aspecto olvidado del cine mudo. Paralelamente, se han desarrollado investigaciones, en varios centros europeos, para comprender cómo, después de muchos años, se podian restablecer y restaurar las coloraciones de la época con tecnologías, metodologías y películas modernas.

El trabajo científico de Luciano Berriatúa realizado con las pelí culas de Murnau ha permitido poder ver en copias completas y filológicamente correctas las películas del gran maestro alemán. Hasta hace pocos años se creía que Nosferatu era una película en blanco y negro; las investigaciones llevadas a cabo en las fit motecas de todo el mundo has permitido descubrir que la película estaba en realidad coloreada por imbibiciones y virajes. La restauración realizada ha podido de esta manera restablecer las coloraciones y el montaje correctos (demostrando además que no siempre la "versión más larga" es la más correcta). La restauración de Fausto testimonia los resultados tan positivos que un trabajo de restauración, si sigue un método científico, puede alcanzar. De Fausto se conocian solamente unas copias muy ale jadas del montaje (que estaba incompleto) y la calidad fotográfica de la versión original. Las investigaciones, durante años, de Luciano Berriatúa han permitido descubrir que de esta película se montaron más ediciones en el transcurso de los años: la versión del preestreno en el UFA Palace de Berlín en agosto de 1926, la primera edición alemana (octubre de 1926), la segunda edición alemana (finales de los años 20) y la tercera edición alemana (inicio de los años treinta). Paralelamente a las tres ediciones realizadas para el mercado alemán, Berriatúa ha localizado una versión para el mercado americano montada en 1926 por el mismo Murnau. Naturalmente no quedaba ningún material de la primera presentación en Berlín de 1926, pero gracias a la recuperación del negativo de la versión americana, del negativo de la tercera edición alemana, de una copia positiva de la época destinada al mercado danés, del negativo de la versión francesa 


\begin{tabular}{|l|}
\hline Investigación \\
Restauración \\
cinematográfica. Tierra de \\
nadie
\end{tabular}

(que conservaba los flash title originales alemanes) y de una ilus tre serie de informaciones derivadas de la recuperación de la escenificación, apuntes del montaje, partituras, revisiones de censura, lista de subtitulos y de otras informaciones obtenidas de fuentes secundarias (revistas de cine de la época) ha sido posible restaurar y reconstruir el Fausto tal y como se mostró por primera vez en público en agosto de 1926. El proyecto de Berriatúa prevé también la restauración de las otras ediciones y versiones de la película.

Cada vez es más frecuente que, junto a la difusión televisiva de las películas restauradas, los propietarios de los derechos (Canal Plus, Gaumont, etc.) organicen también la salida de las películas en DVD. Recientemente, la sociedad de producción y distribución francesa MK2, al mismo tiempo que la proyección en las salas cinematográficas de las versiones restauradas, editaron en DVD las películas de Charles Chaplin. La situación del mercado americano de los DVD, respecto a la situación europea, está más desarrollada y se asiste a una actualización regular de los catálogos de ventas.

Siempre en el contexto americano, hemos asistido en los últimos años a importantes operaciones de restauración promovi das como las Majors. Compañías como la Sony Columbia Picture ejecutan trabajos extremadamente complejos. Vale la pena citar el ejemplo de la restauración de una película de 1969 como Easy Rider. El negativo original de la película estaba des truido y el color estaba seriamente comprometido. La restauración, llevada a cabo en colaboración con el director de fotografía de Easy Rider, ha implicado por tanto la utilización de varios elementos derivados de copias positivas distintas y el recurso de las tecnologías digitales (sobre el $25 \%$ del negativo) para restablecer la obra del mejor modo posible. Otro ejemplo nos lo ofrece la UCLA Film y la Televisión Archive de Los Ángeles que colabora con las principales productoras de Hollywood: la restauración de The Nigth of the Hunter (La noche del cazador), realizada en colaboración con la MGM, representa un caso de restauración completa y ejemplar porque paralelamente al trabajo des arrollado en la película, se han restaurado de manos de Bob Gitt (figura eminente entre los restauradores americanos) también los out-takes de la película que contenian todos las pruebas, cortes y descartes, que hacen un total de casi ocho horas: un rico material que permite hacer hoy una lectura más compleja del trabajo de Charles Laughton.

\section{Una, dos, diez versiones}

En el ámbito de las artes figurativas, una misma obra puede tener la calificación de original, copia de autor, copia de bodega, copia de otro artista, réplica de autor, réplica de bodega, réplica fiel, réplica con variantes.
En el ámbito del cine, para cada película existen distintas versiones y/o ediciones, a menudo contradictorias entre ellas, pero todas legítimas y con una historia interna. El mismo proceso de producción de una película implica la existencia de multitud de materiales heterogéneos: negativos de cámara, material de prueba, copias, elementos intermedios de imagen y sonido (contratipos y lavander), copias positivas (en lengua original, dobladas, subtituladas, etc.), copias para el pase televisivo (a veces con montajes diferentes), descartes, escenas censuradas. A través del análisis de todos estos materiales y de las fuentes documentales (revisiones de censura, documentos de producción, revistas de cine, etc.) es posible establecer la existencia de distintas versiones de una película. Por tanto, no se puede hablar de originales sino de autenticidad.

Es la autenticidad lo que se estudia y se busca, en cuanto concepto más complejo que contiene en sí mismo el tiempo de la obra. Cada versión es auténtica porque es testigo de una intención o de una situación. El respeto de la autenticidad obliga también a la valoración de la múltiple y estratificada historicidad y a prestar una máxima atención sobre el contexto en que la obra ha sido transmitida.

Hasta hace poco tiempo, se tendia a clasificar las restauraciones de las posibles versiones de una película en función de la siguien te división (establecida por E. Bowser en 1990): la película tal y como había sido encontrada, la película como en la primera presentación pública, tal y como había sido pensada originalmente por su director (antes de que interviniesen por ejemplo la censura o los problemas con la producción), la película presentada en una versión que tuviese en cuenta la existencia de un público moderno y su modo diferente de percibir el espectáculo cinematográfico, la película reinterpretada por un artista contemporáneo. En la última década, la deontología vinculada a la restauración se ha desarrollado y ha tomado conciencia de que cada película supone una serie de problemáticas especificas, mucho más complejas de las propuestas por Bowser, ligadas a la época y a la supervivencia actual de más versiones y/o ediciones. Este nodo metodológico es fundamental para entender el trabajo de restauración: es necesa rio hacer una clara separación entre las versiones que existían en la época de estreno de la película y también posteriormente (importancia de la investigación extra-fílmica) y los elementos de estas versiones que sobrevivan aún en la actualidad (búsqueda de las copias, censo). La decisión sobre qué versión restaurar va unida de manera indisoluble a esta problemática.

\section{El método}

\section{a) Proceso de investigación preliminar y diagnóstico de los materiales}

El procedimiento de restauración de una película es un proceso que prevé distintas fases y que se distribuye en un período de tiempo más bien largo. La fase preliminar de cada trabajo de res 


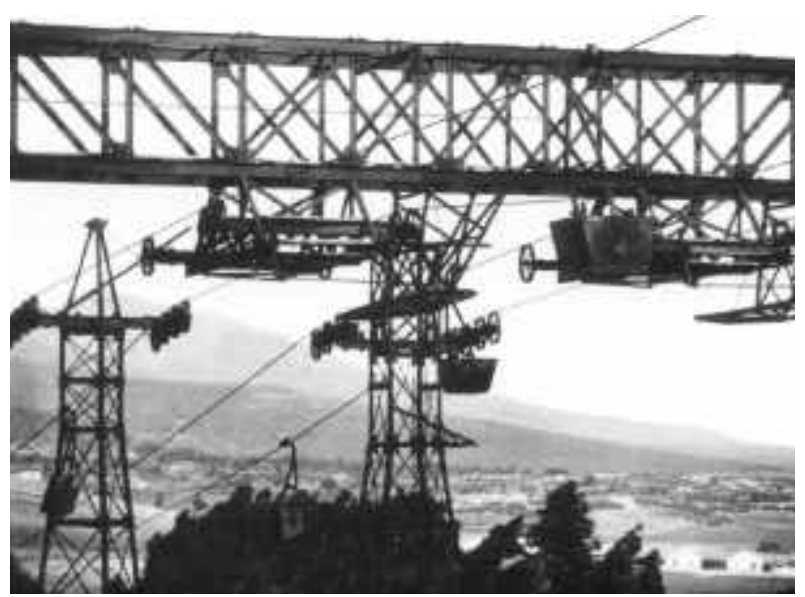

tauración consiste en la búsqueda en todos los archivos del mundo de posibles copias existentes de la película que se quiere restaurar (censo). Esta fase se desarrolla paralelamente con la búsqueda de materiales documentales (extra-filmicos) que proporcionen indicaciones sobre la historia de la película y que puedan también ofrecer informaciones útiles para el trabajo de restauración (por ejemplo, la recuperación del pase de censura junto con la lista de los subtítulos o el metraje original). Una vez reseñadas todas las copias de la película que se va a restaurar, realizadas sobre cualquier soporte y formato, y reagrupadas las informaciones procedentes de los fondos documentales, se puede comenzar con las propias operaciones de restauración.

La valoración y estudio de las copias reseñadas es la primera fase y permite establecer las relaciones de parentesco existentes entre los distintos testimonios, establecer cuál es la copia más antigua la más completa, etc. Gracias al estudio de las fuentes extra-filmi cas será posible esclarecer a qué versión y/o edición pertenecen las copias encontradas. El examen detallado de una serie de informaciones contenidas físicamente en la película permitirá en cambio comprender si estamos ante una copia de primera generación o de una reimpresiones posteriores, sabremos cuál es el método con el que ha sido impresionada y montada, los distintos tipos de coloración, el stock de la película, si se han efectuado intervenciones, transformaciones, alteraciones, etc.

Al mismo tiempo que se analizan las copias, se redacta una evaluación en profundidad sobre el estado de conservación (físico y quimico) de cada elemento y se hacen los test de impresión. Existen similares problemas para cada tipo de soporte (roturas, desgarros, laceraciones, etc.) pero también se presentan problemas concretos vinculados al soporte usado y a las condiciones en las que se han conservado. El tipo de película y el procedimiento fotográfico (blanco y negro o en color, Technicolor o Eastmancolor, etc.) influyen en el estado de

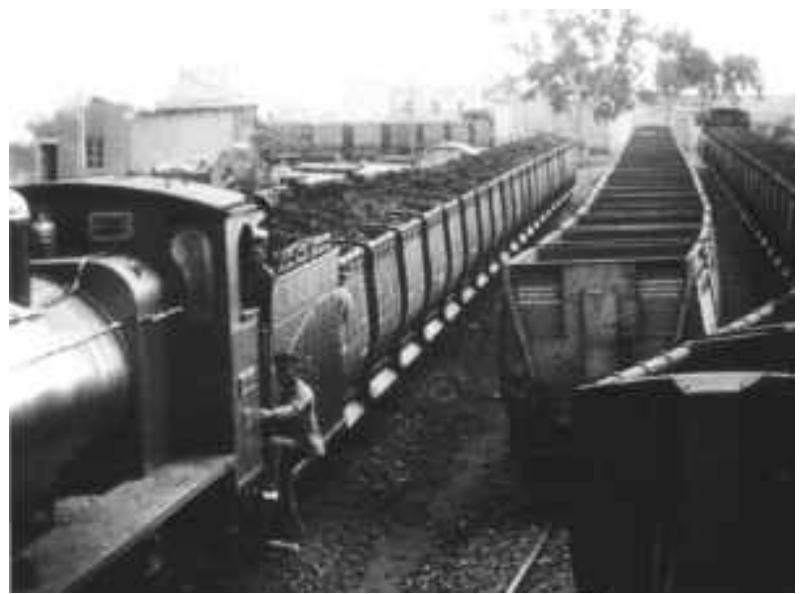

conservación. El nitrato de celulosa tiende a encogerse, a volverse extremadamente frágil y la imagen puede llegar a disolverse incluso completamente; las películas en soporte de seguridad pueden ser afectados por el ya citado Vinegar syndrome o "síndrome del vinagre".

\section{b) Proceso de planificación y modalidad de intervención} Una vez finalizado la fase de diagnóstico, se redacta un informe que contiene el examen de los materiales y el consiguiente proyecto de restauración. En esta fase se decide qué versión de la pelí cula y/o edición se va a restaurar, y la modalidad de intervención. La casuística es casi infinita e inspirándose en la filología literaria, también en el campo de la restauración cinematográfica está vigente el principio formulado por Michele Barbi según el cual cada texto tiene su propia solución crítica.

El primer objetivo de cada intervención de restauración es por tanto definir qué versión y/o edición restaurar. Existe una razón de carácter ético que impone la honestidad de que sea transparente el trabajo de restauración y el deber de informar al espectador sobre qué será exactamente lo que verá; este concepto trata de respetar el principio expuesto por Brandi según el cual "cada intervención de restauración no haga imposible, es más, facilite posi bles intervenciones futuras."

En las otras artes cuenta la correcta conservación. Para el cine esto no es suficiente; una copia positiva de una película restaurada, cada vez que sea proyectada, sufrirá daños $y$, por tanto, es necesario, a través del proceso de restauración, crear nuevos elementos destinados exclusivamente a la conservación (contratipos, lavander, negativos duplicados).

\section{c) La técnica analógica (restauración fotoquímica)}

Establecido el procedimiento, las películas sobre las que será necesario restaurar se someten a varias intervenciones. La prime- 


\begin{tabular}{|l|}
\hline Investigación \\
Restauración \\
cinematográfica. Tierra de \\
nadie
\end{tabular}

ra fase consiste en la reparación de los daños físicos: perforaciones rotas o eliminadas, juntas abiertas o defectuosas, desgarros o laceraciones. Esta intervención puede requerir, en función de las condiciones físicas de las copias o de su longitud, de pocas horas o de bastantes dias de trabajo. Restablecida así la funcionalidad, la película se lava en máquinas especiales (regeneración) con disolventes que no dañan la emulsión, con el fin de eliminar del soporte y de la emulsión la suciedad, el polvo, el aceite de los proyectores, etc. La copia ya está lista para generar el primer elemento de conservación a través de la impresión. El restaurador dispone de distintos tipos de impresoras: a contacto y ópticas. El avance de la película por la impresora, cualquiera que sea, puede ser continuo o intermitente. Podemos afirmar que, en la mayoría de los casos, cuando se restauran películas antiguas a partir de copias en estado crítico de conservación, se usa la impresora óptica bajo líquido con avance intermitente (regulable). La impresión bajo líquido permite eliminar o reducir gran parte de los arañones existentes en el soporte y la emulsión gracias al empleo de un líquido con un índice de refracción similar al de la película y que permite a la luz que la atraviesa que se refracte de manera correcta sobre la película virgen. Eventuales problemas químicos vincu lados a la imagen (por ejemplo, el inicio de la degradación quími ca) pueden corregirse o reducirse modificando el revelado de la película. Si la restauración se hace partiendo de una copia positiva tendremos ahora un contratipo o un internegativo; si en cambio el elemento de partida es un negativo, la impresión habrá generado un contratipo positivo (lavander) o bien un interpositivo. Si el objeto de restauración es sonoro, la escena y la columna se tratan y restauran separadamente hasta el momento de la impresión de la copia positiva final que es combinada.

Esta operación se repetirá en todas las copias que se usen para efectuar la restauración de una película. Los nuevos elementos generados (matrices) se pueden integrar entre sí o bien montarse en función de las intervenciones previstas desde el plano de la restauración. Pueden sustituirse o integrarse (en parte o completamente) los subtitulos, corregirse los errores de montaje, montarse las partes que faltan procedentes de otra copia, etc.

Terminada la operación de montaje y revisión de los nuevos elementos creados se puede por último proceder a la impresión de los nuevos elementos de conservación y de las copias positivas para proyectar.

\section{d) La técnica digital}

Si la restauración digital del sonido es una práctica generalizada y llevada a cabo en la mayoría de los laboratorios desde hace casi una década, la restauración digital de la imagen está aún en fase experimental y es raro encontrar obras completamente restauradas con técnicas digitales. Es más frecuente, y más viable desde el punto de vista económico, el caso en que en un proceso de res tauración analógica se efectúan intervenciones con técnicas digitales en pequeñas partes que presentan graves problemas (asi ha sucedido, por ejemplo, con las restauración de las películas de Chaplin The Kid y The Circus, a cargo de la Cineteca de Bolonia en 1999 y en 2003). A diferencia del procedimiento analógico (fotoquímico), las tecnologías digitales permiten registrar y duplicar sin perder ninguna información. Naturalmente el procedimien to de restauración y la maquinaria cambian respecto a los procedimientos normales usados en el ámbito analógico. Las imágenes de la películas se obtienen en soporte digital (data files) a través de escaneado directo (film escáner) o a través del telecinema (telecine unit). De esta forma se transfieren las imágenes de la película a soportes digitales (D5, D6, D7, Digibeta, DVC PRO, etc.), legibles por los software que permitirán intervenir en la imagen. Parte de las intervenciones, como por ejemplo la eliminación de los arañones y la estabilidad del cuadro, pueden ser llevadas a cabo incluso de forma automática por modernas workstation. Sobre un nuevo archivo se registra paso a paso la versión restau rada de la película que será por último "descargada" sobre un nuevo negativo de $35 \mathrm{~mm}$ del que se impresionarán posteriormen te, a través de un proceso fotoquímico, las copias positivas destinadas a la proyección. Éste es el procedimiento correcto para la restauración digital de la película al generar al final del proceso de restauración un negativo en película de $35 \mathrm{~mm}$. El "regreso" final a la forma analógica es fundamental en el sentido de que permite poder disponer de material en $35 \mathrm{~mm}$ destinado a la conservación. De hecho, mientras que se conocen los métodos de conservación de las películas, las investigaciones y experimentaciones de archivar, la conservación y la transferencia a nuevos soportes están aún en proceso. La restauración debe implicar la correcta conservación en el tiempo y, como ya decíamos al comienzo de nuestro artículo, el soporte más seguro continúa siendo la película cinematográfica de $35 \mathrm{~mm}$.

\section{La documentación de la restauración y la reversibilidad de las intervenciones}

El proceso de restauración, analógico y digital, prevé no sólo fases de reparación y duplicación, sino también momentos en los que actúa directamente sobre la película modificando y/o integrando partes de la misma. Cada intervención que se realiza debe ser documentada y reversible.

La documentación relacionada con la restauración de una pelí cula es de dos tipos: un primer modo, fundamental, consiste en introducir al comienzo o al final de la película restaurada una breve explicación que explique los materiales de partida y, a grandes líneas, el tipo de intervención seguida. El segundo consiste en la creación de un dossier de restauración que testimonie el procedimiento de los trabajos realizados. 


\section{Conservar, restaurar, mostrar}

¿Existe la unidad de la obra cinematográfica sin la proyección en la sala? ¿Quién sostendría que es posible transferir el Panteón de la Acrópolis de Atenas a un monitor de un ordenador sin destrozar de manera irremediable la unidad de la obra de arte? ¿Entonces por qué el consumo de historia del cine se da hoy, incluso en la universidad, a través de vhs o el dvd? Tras salvar la película, creemos que actualmente existe otra prioridad igualmen te urgente, que consiste en salvar el cine en su integridad como experiencia colectiva, porque ha supuesto uno de los grandes momentos de la historia del siglo XX.

El tiempo no actúa sólo sobre la degradación química y física de una película; en estos cien años hemos visto modificarse profundamente el espectáculo cinematográfico. Desde 1895 hasta hoy la técnica y la modalidad de disfrutar el cine han cambiado tanto que hoy sería imposible mostrar en una sala moderna una película original de los primeros años del siglo.

El arte mudo se canceló con la llegada del sonoro, primero con disco, después inciso en la película de modos infinitamente diversos. Citizen Kane (Ciudadno Kane) fue imaginado con un sonido revolucionario de una amplitud extraordinaria. Vertigo y The Man who knew too much (El hombre que sabía demasiado) se rodaron en Perspecta Sound, un sistema que permitía una pri mera estereofonía óptica. Lola Montes, como gran parte del cine espectacular producido entre los años 50 y 70, utilizaba las cuatro pistas magnéticas para obtener una estereofonía prácticamente perfecta.

Las salas cinematográficas se han modificado radicalmente desde los años 10 hasta la actualidad para acoger estas profundas transformaciones. La pantalla se modificó en amplitud y proporciones pasando de 1:1,33 del mudo al 1:2 del cinemascope. La sala cinematográfica, aquel templo de la visión y del placer que ha acunado los sueños de millones de espectadores, se ha transformado del Grand Café de la primera proyección Lumière a los multicines de la actualidad, pasando por decenas de modelos que han marcado las épocas del consumo cinematográfico. Mostrar correctamente el cine del pasado significa también reconstruir las condiciones técnicas más cercanas a aquellas en que la película fue concebida y disfrutada. Una película en Cinemascope no puede verse sólo a través de la pantalla televisiva, así como una obra lírica no puede ser disfrutada sólo a través de formas de registro. El cine nació y se concibió para mostrarse en las salas oscuras, delante de un público de espectadores, en grandes pantallas blancas sobre las que brillaba la luminosidad y transparencia de la película. Parte esencial de la restauración es el regreso de una película a la sala, a los lugares que permitan la correcta y completa visión de la obra.

\section{Bibliografía}

ANDERSON, G.B. (1990) Niente musica fino al punto indicato: la ricostruzione de "Intolerance" con la partitura di Joseph Carl Breil, en Griffithiana, n 38-39, 1990

BORDE, R. (1983) Les cinémathèques. París: Éditions L'Age d'Homme, 1983

BOWSER, E.; KUIPER, J. (1991) Handbook for Film Archives. New-York-London: Garland, 1991

BRANDI, C. (1977) Teoria del restauro. Torino: Einaudi, 1977

BROWN, H. (1990) Physical characteristics of early films as aids to identification. Bruxelles: FIAF, 1990

CANOSA, M. "Per una teoria del restauro cinematografico" en Storia del cinema mondiale, vol. 5, Torino, 2001

CHERCHI USAI. (2001) "La cineteca di Babele" en Storia del cinema mondiale, vol. 5, Torino, 2001

DESMET, N. (1993) Restauration des films teintés et virés. Bruxelles: Cinémathèque Royale, 1993

FARINELLI, G.L.; MAZZANTI, N. (1994) "L'immagine ritrovata" en cinema \& cine ma, $n^{\circ} 63,1992$

FIAF. Code of ethics, Federation Internationale des Archives du Film. Bruxelles, 1998

HOUSTON, P. (1994) Keepers of the frame: the film archives. London, British Film Institute, 1994

KUIPER, E. (1999) "La memoria degli archivi” en Cinegrafie, n 12, junio 1999

MAZZANTI, N.; FARINELLI, G.L. (2001) "II restauro del film. Metodo e tecnica" en Storia del cinema mondiale, vol. 5, Torino, 2001

PAÏNI, D. (1992) Conserver, montrer -Où l'on ne craint pas d'édifier un musée pour le cinéma. Paris: Yellow Now, 1992

PAÏNI, D. (1996) La persistance des images - tirages, sauvegardes et restaurations dans la collection films de la Cinémathèque Française de 1992 à 1996. Paris: La Cinémathèque Française, 1996

REDISCOVERING the role of film archives: to preserve and to show. Actas del simposio, Lisboa, 1989

SUROWIEC, C. (1996) The Lumière project. The European Film Archives at the Crossroads. Lisboa, 1996

TECHNICAL Manual of the FIAF Preservation Commission. Bruxelles, 1987

TOULET, E.; BELAYGUE, CH. (1991) Cinémemoire (catalogue). Paris, 1991

\section{Nota}

Texto originalmente publicado en italiano bajo el título "Restauro e conservazione" en I'Enciclopedia del Cinema, vol. IV, pp. 629-643, Roma 2004. Agradecemos al Istituto della Enciclopedia Italiana que haya autorizado desinteresadmente su reproducción. 